\title{
Effects of androgen and progestin on the proliferation and differentiation of osteoblasts
}

\author{
XINCHEN WU ${ }^{1}$ and MENGQI ZHANG ${ }^{2}$ \\ ${ }^{1}$ Department of Biomedical Engineering, Stevens Institute of Technology, Hoboken, NY 07030, USA; \\ ${ }^{2}$ Department of Pediatrics, Peking Union Medical College Hospital, Beijing 100730, P.R. China
}

Received January 15, 2018; Accepted July 13, 2018

DOI: $10.3892 /$ etm.2018.6772

\begin{abstract}
Osteoporosis is liable to affect patients with gonadal hormone deficiency, and a supplement of androgens may be used to increase bone density of patients with osteoporosis. Since the androgens currently used may cause severe side effects, it is useful to investigate the effect of other androgens and progestin on bone improvement. The aim of the current study was to investigate the effects of pregnenolone (Preg), androstenedione (AD), etiocholanolone (Etio), androsterone (An), nandrolone (NA) and testosterone (T) on the proliferation and differentiation of osteoblasts for potential clinical applications. Human osteoblasts were cultured and treated with androgens and progestin, including Preg, $\mathrm{AD}$, Etio, An, NA, and T, at concentrations of $0,10^{-10}, 10^{-8}, 10^{-6}$ and $10^{-5} \mathrm{~mol} / \mathrm{l}$. The levels of cell proliferation, alkaline phosphatase (ALP) activity and osteocalcin content were measured and assessed. Preg, AD, Etio, An, and T at concentrations of $10^{-10}$ and $/$ or $10^{-8} \mathrm{~mol} / 1$ significantly improved osteoblast proliferation. NA at concentrations of $10^{-10}, 10^{-8}, 10^{-6}$ and $10^{-5} \mathrm{~mol} / 1$ also significantly improved osteoblast proliferation. Preg, AD, Etio, An, NA, and T significantly increased ALP activity and osteocalcin content. The present study demonstrated, for the first time, that Preg, AD, Etio, An, and NA could improve the proliferation and differentiation of osteoblasts in vitro.
\end{abstract}

\section{Introduction}

The skeleton provides a mechanical structure for supporting the human torso, protects internal organs, stores minerals and facilitates movement. Bone has a number of important roles, including making red and white blood cells, and generating and secreting various active substances capable of modulating biological function in tissues and organs (1-3). Bone tissue, an

Correspondence to: Dr Xinchen Wu, Department of Biomedical Engineering, Stevens Institute of Technology, 1 Castle Point Terrace, Hoboken, NY 07030, USA

E-mail: xinchenwu1990@163.com

Key words: osteoblasts, pregnenolone, androstenedione, etiocholanolone, androsterone, nandrolone, testosterone, androgen endocrine organ, may directly or indirectly modulate skeletal muscle metabolism (4). In recent decades, osteoporosis has become one of the major diseases in the elderly population. Worldwide, millions of people suffer from osteoporosis and are at a high risk of fractures due to low bone mass (5). Numerous cytological studies on the prevention and treatment of osteoporosis have been conducted in the course of drug development (6). Osteoblasts and osteoclasts are responsible for forming, destroying, remodeling and repairing the organic and inorganic matrix that constitutes bones (6-9). Bone metabolism, which is associated with normal growth, fractures and osteoporosis due to postmenopausal and age-related osteopenia, is highly regulated and balanced between bone formation via osteoblasts and bone resorption via osteoclasts (10). Investigations on the proliferation and differentiation of osteoblasts are crucial to studies on the formation of bone and its constant remodeling.

Clinical observations indicate that osteoporosis is often diagnosed in older patients (age, $>50$ years) or post-menopausal women and the practice of hormone replacement therapy improves bone density in osteoporosis patients (11-16). The effects of both estrogen and androgen on the maintenance of bone mass have been widely studied in the past few decades (17). It is known that estrogen has positive effects on bone formation and the inhibition of bone resorption. Current estimates state that approximately $20 \%$ of Americans with osteopenia or osteoporosis are male (18), which suggests that men were better protected against osteoporosis and osteoporotic fractures compared with women. Some evidence suggests that older men have a risk of osteoporosis when their androgen levels decrease, and androgenic steroids have the proven ability to promote osteogenesis (19). On the other hand, muscle and bone are in constant interaction. With aging, there is a progressive decline in muscle mass, known as sarcopenia, as well as in bone mass, known as osteopenia/osteoporosis (19). The above studies have demonstrated that androgen plays a significant role in the maintenance of bone mass and muscle, with benefits in the treatment of osteoporosis.

However, the anabolic steroids involved in hormone replacement therapy may cause severe side effects, including changes in mood and libido, increase of aggression, and pathological cardiovascular symptoms $(20,21)$. The intake of steroids with strong androgenic pharmacological actions, including testosterone (17 $\beta$-hydroxy-androst-4-en-3-one; T) 
and dihydrotestosterone (17 $\beta$-hydroxy-5 $\alpha$-androstan-3-one; DHT), induce virilescence in women (22). Therefore, other related steroids should be considered as short-term substitutes or supplements to attenuate these adverse effects in the treatment of osteoporosis.

Steroids with weak androgenic effect and the precursors of androgenic hormones may be considered as candidates. Pregnenolone (3 $\beta$-hydroxy-5-pregnen-20-one; Preg) is an endogenous progestin and an essential precursor for all other steroid hormones (23). Androstenedione (androst-4-ene-3,17-dione; AD) is an endogenous androgen and an intermediate in the biosynthesis of T. It is also the precursor of certain androgens and estrogens (24). Etiocholanolone ( $3 \alpha$-hydroxy- $5 \beta$-androstan-17-one; Etio) is an endogenous $5 \beta$-androstane steroid, which is one of the major excreted metabolites of testosterone (25). Androsterone ( $3 \alpha$-hydroxy-5 $\alpha$-androstan-17-one; An), an endogenous steroid hormone and putative pheromone (26), is a weak androgen with one-seventh of the androgenic effect of $\mathrm{T}$ (27). Unlike the naturally occurring steroids above, nandrolone (17 $\beta$-hydroxy19-nor-4-androsten-3-one; NA) is a synthetic anabolic-androgenic steroid derived from T. A previous study has described that the positive effects of NA include reducing time to bone consolidation (28). The chemical structures of these steroids are illustrated in Fig. 1.

To the best of the authors' knowledge, the effects on osteoblasts of progestin and the aforementioned androgens have not been reported. $\mathrm{T}$, the primary male sex hormone, can be converted to estrogen in vivo, which was considered to be the mechanism for the effectiveness of $\mathrm{T}$ in bone regeneration in a previous study (29). Although the stimulatory effect of $\mathrm{T}$ incorporated into polymer-bioceramic on osteoblast proliferation has been described previously (30), the independent effect of $\mathrm{T}$ on osteoblast proliferation was determined in this study.

The aim of the present study was to reveal the proliferation and differentiation effects of Preg, AD, Etio, An and NA on human osteoblasts and to explore the potential application of Preg, AD, Etio and An in treating osteoporosis.

\section{Materials and methods}

Materials. Phosphate-buffered saline, Dulbecco's modified Eagle's medium (DMEM) with low glucose, trypsine-ethylenediaminetetraacetic acid (EDTA) and penicillin/streptomycin were obtained from Gibco (Thermo Fisher Scientific, Inc., Waltham, MA, USA). Fetal bovine serum(FBS) was purchased from Biological Industries (Kibbutz Beit Haemek, Israel). Preg, AD, Etio, An, NA and T were from Sigma-Aldrich (Merck KGaA, Darmstadt, Germany).

Cell culture and drug intervention. Human fetal osteoblasts (hFOB1.19; ATCC CRL-11372; American Type Culture Collection, Manassas, VA, USA) were thawed and sub-cultured in low-glucose DMEM supplemented with $10 \%$ FBS and $1 \%$ penicillin/streptomycin in a humidified incubator at $37^{\circ} \mathrm{C}$ with $5 \% \mathrm{CO}_{2}$. The medium was changed every 2 days. The cells were trypsinized with $0.25 \%$ trypsin-EDTA and seeded. The culture medium was then changed to the treatment medium, made with low-glucose DMEM, $10 \%$ FBS, $1 \%$ penicillin-streptomycin, $50 \mathrm{mg} / \mathrm{ml}$ ascorbic acid, $0.01 \mathrm{~mol} / 1$ glycerol-2-phosphate, $100 \mathrm{nmol} / 1$ dexamethasone and supplemented with drugs (Preg, AD, Etio, An, NA and T). These drugs were added at various concentrations. The non-drug group $(0 \mathrm{~mol} / \mathrm{l})$ was used as a blank control. The measurement for each concentration was conducted six times, and the mean value was used in analysis.

Cell metabolic activity was assessed with an MTS assay, as described below. Cells were seeded in tissue culture plates at a density of $1 \times 10^{4}$ cells/well and cultured with the treatment medium for $24 \mathrm{~h}$. Each drug was added at concentrations of 0 , $10^{-10}, 10^{-8}, 10^{-6}$ and $10^{-5} \mathrm{~mol} / 1$.

For the measurements of alkaline phosphatase (ALP) and osteocalcin, the cells were seeded in tissue culture plates $\left(5 \times 10^{4}\right.$ cells $\left./ \mathrm{cm}^{2}\right)$ and cultured with the treatment medium for 5 days. The treatment medium was changed every 2 days. Preg, AD, Etio, An, NA and T were added at a concentration of $10^{-10} \mathrm{~mol} / \mathrm{l}$.

Cell proliferation assessment. Cell proliferation was assessed using an MTS assay (CellTiter 96 ${ }^{\mathrm{TM}}$ AQueous Assay; Promega Corporation, Madison, WI, USA), following cell culture for $24 \mathrm{~h}$. The MTS and phenazine methosulfate (PMS) solution were warmed and mixed at a ratio of MTS:PMS=20:1. Then, $200 \mu \mathrm{l}$ of the mixed solution and $1 \mathrm{ml}$ culture medium were added to each well, and the cells were incubated for $2 \mathrm{~h}$ at $37^{\circ} \mathrm{C}$. The absorbance of the supernatant was measured using a spectrophotometer at a wavelength of $490 \mathrm{~nm}$ and the optical density (OD) values recorded.

ALP activity assay. An ALP assay was performed following 5 days of cell culture with the drugs at a concentration of $10^{-10} \mathrm{~mol} / \mathrm{l}$. The activity of ALP, an exo-enzyme used as the marker of the osteoblastic phenotype, was measured using an Alkaline Phosphatase Assay kit (Anaspec, Inc., Fremont, CA, USA) according to the manufacturer's protocol. Briefly, the cells were lysed in $600 \mu 1$ lysis buffer provided in the kit under continuous scratching with a pipette tip. The lysate was then centrifuged for $15 \mathrm{~min}$ at $10,000 \mathrm{x} \mathrm{g}$ at $4^{\circ} \mathrm{C}$. The supernatant was added to a non-tissue culture treated plate and p-Nitrophenyl Phosphate Disodium (Pnpp) ALP substrate solution was added to each well. The plate was incubated at $37^{\circ} \mathrm{C}$ for $1 \mathrm{~h}$. The stop solution provided with the kit was added to each well following incubation and the absorbance of the solution was measured using a spectrophotometer at a wavelength of $405 \mathrm{~nm}$. The values of ALP activity (U/1) were recorded.

Osteocalcin secretion. Osteocalcin, also called bone $\gamma$-carbo xyglutamic-acid-containing protein (BGP), is one of the most abundant proteins in bone and is produced exclusively by osteoblasts; it has been used as a serum marker of osteoblastic bone formation (31). A BGP assay was performed on cells cultured with the drugs at a concentration of $10^{-10} \mathrm{~mol} / \mathrm{l}$ for 5 days. A total of $25 \mu \mathrm{l}$ culture medium was analyzed using a BGP ELISA kit (cat. no. JL19437-48T; Shanghai Jianglai Bio-Technology Co., Ltd., China) according to the manufacturer's protocol. The BGP concentration $(\mu \mathrm{g} / \mathrm{l})$ was recorded.

Statistical analysis. A one-way analysis of variance and Tukey's post-hoc test were used to assess significant differences. Data are presented as the mean \pm standard deviation. 
A<smiles>C[C@]12CCC3([C@H]4CCC5=CC(=O)CC[C@]5(C)[C@H]43)[C@@]1(C)CCC2=O</smiles>

D<smiles>C[C@]12CC[C@H]3[C@@H]4CCC(=O)C=C4CC[C@H]3[C@@H]1CCC2O</smiles>

B<smiles>C[C@]12CC[C@H](O)C[C@H]1CC[C@@]1(C)[C@H]2CC[C@@H]2CCC(=O)[C@@]21C</smiles><smiles>CC(=O)[C@@H]1CC[C@H]2[C@@H]3CC=C4C[C@@H](O)CC[C@]4(C)[C@H]3CC[C@@]21C</smiles>

C<smiles>C[C@]12CC[C@H]3[C@@H](CC[C@@H]4C[C@H](O)CC[C@]34C)[C@@H]1CCC2=O</smiles><smiles>C[C@]12CC[C@H]3[C@@H](CCC4=CC(=O)CC[C@@]43C)[C@@H]1CCC2O</smiles>

Figure 1. Chemical structures of androgens and progestin. (A) Androstenedione; (B) androsterone; (C) etiocholanolone; (D) nandrolone; (E) pregnenolone; and $(\mathrm{F})$ testosterone.

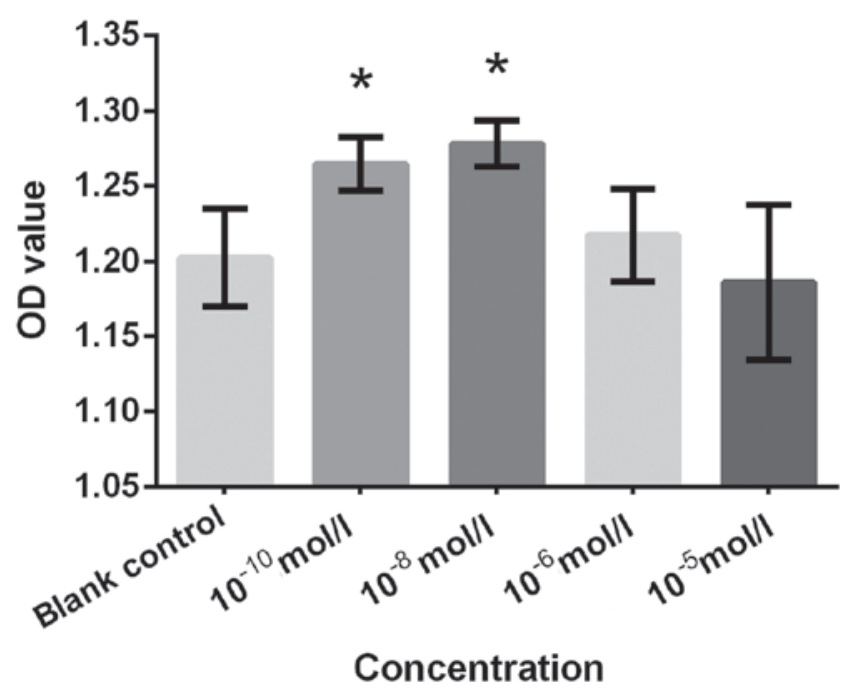

Figure 2. Proliferative effect of pregnenolone. ${ }^{*} \mathrm{P}<0.05$ vs. blank control. OD, optical density.

SPSS version 20 (IBM Corp., Armonk, NY, USA) was used for statistical analysis. $\mathrm{P}<0.05$ was considered to indicate a statistically significant difference.

\section{Results}

Cell proliferation. The proliferation effects of cells treated with drugs at concentrations of $0,10^{-10}, 10^{-8}, 10^{-6}$ and $10^{-5} \mathrm{~mol} / 1$ were analyzed using an MTS assay. The measured OD values for Preg, AD, Etio, An, NA and T with various concentrations were plotted and are presented in Figs. 2-7, respectively. Cells treated with $10^{-10}$ and $10^{-8} \mathrm{~mol} / \mathrm{l}$ Preg exhibited significantly increased proliferation rate compared with the blank control group (Fig. 2). This finding was consistent with the effective concentrations for $\mathrm{AD}$ and Etio, which also induced a significant increase in proliferation at $10^{-10}$ and $10^{-8} \mathrm{~mol} / 1$ compared with the control (Figs. 3 and 4). An significantly increased cell proliferation at $10^{-10} \mathrm{~mol} / \mathrm{l}$ (Fig. 5). T was not as effective as expected for cell proliferation at these

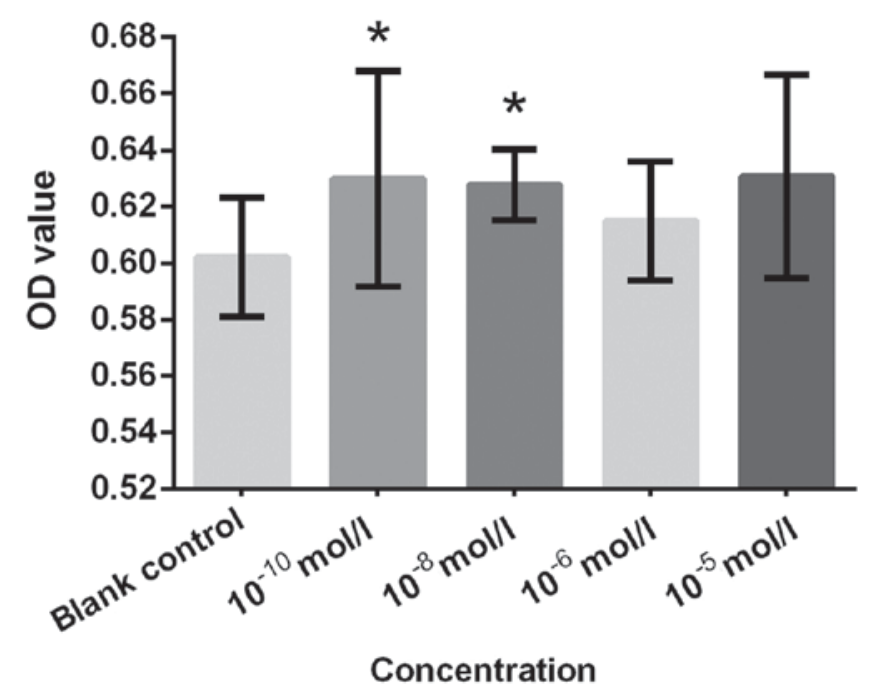

Figure 3. Proliferative effect of androstenedione. " $\mathrm{P}<0.05$ vs. blank control. OD, optical density.

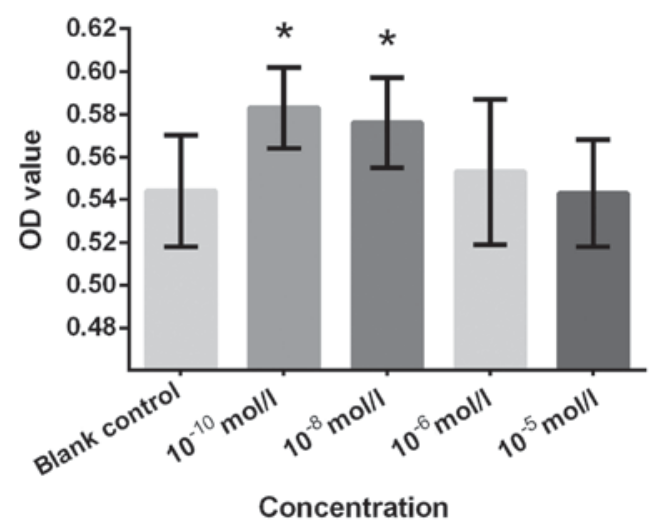

Figure 4. Proliferative effect of etiocholanolone. " $\mathrm{P}<0.05$ vs. blank control. OD, optical density.

concentrations. Nevertheless, the results of $\mathrm{T}$ still indicated that proliferation was significantly increased in the $10^{-10}$ and 


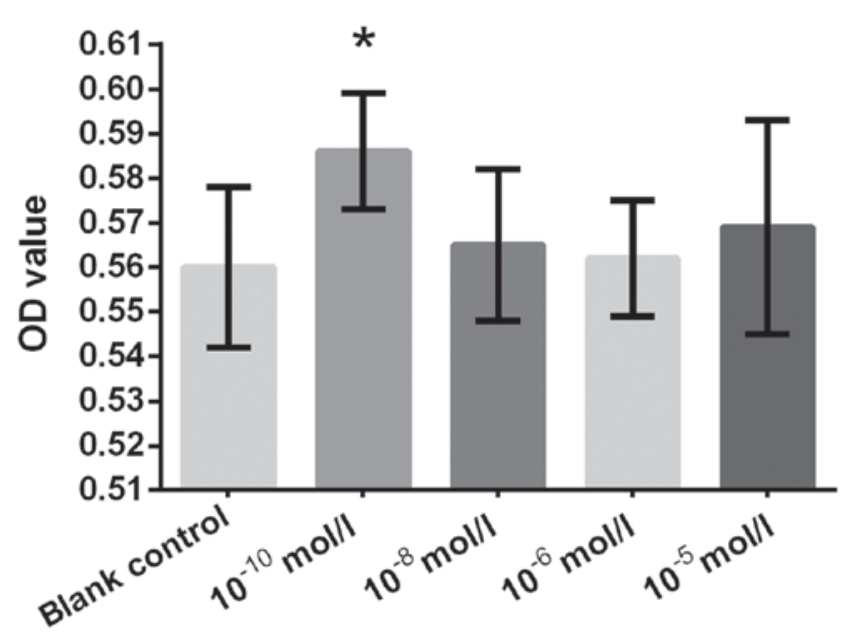

Concentration

Figure 5. Proliferative effect of androsterone. ${ }^{*} \mathrm{P}<0.05$ vs. blank control. OD, optical density.

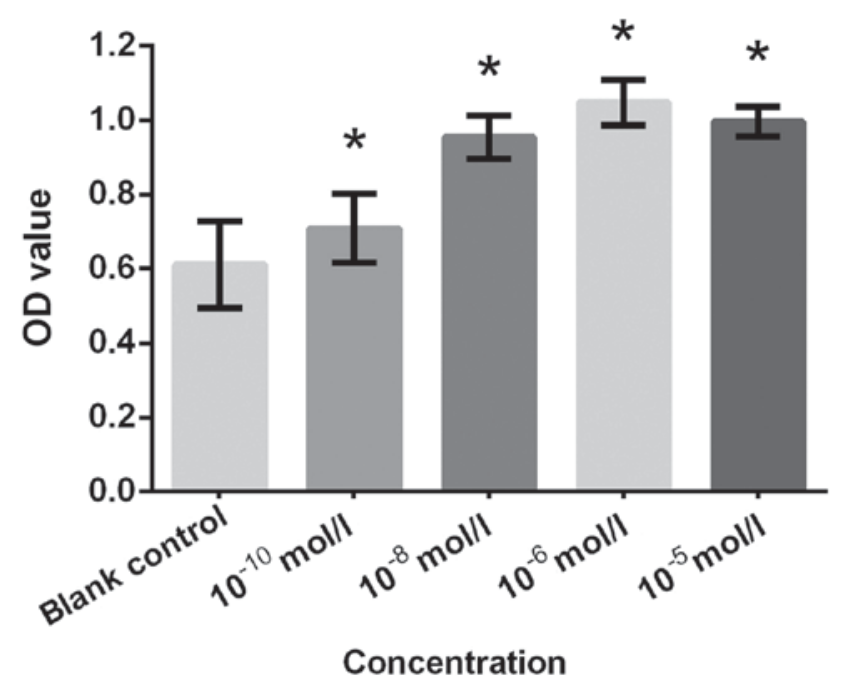

Figure 6. Proliferative effect of nandrolone. ${ }^{\text {"P }}<0.05$ vs. blank control. OD, optical density.

$10^{-8} \mathrm{~mol} / \mathrm{l}$ groups compared with the control group (Fig. 7). These results suggested that Preg, AD, Etio and An should be considered functional steroids in certain situations. It was also suggested that Etio and An would be more effective at $\sim 10^{-10}$ and $\sim 10^{-8} \mathrm{~mol} / \mathrm{l}$. Preg and AD exhibited a similar result. NA at concentrations of $10^{-10}, 10^{-8}, 10^{-6}$ and $10^{-5} \mathrm{~mol} / 1$ demonstrated significantly increased proliferation compared with the blank control (all $\mathrm{P}<0.05$; Fig. 6 ). T plays a key role in the physiological process for males and females, and is essential for health (22) and for the prevention of osteoporosis (32). The differences in effect on proliferation rate between $\mathrm{T}$ and the respective steroid (Preg, AD, Etio An and NA) at concentrations of 10 10 and $10^{-8} \mathrm{~mol} / 1$ were inspected in which the ratio of $\mathrm{OD}_{\text {drug }}$ to $\mathrm{OD}_{\text {blank }}$ was utilized as a parameter. No obvious differences in proliferation efficiency between $\mathrm{T}$ and the respective steroid (Preg, AD, Etio, An and NA) at the concentration of $10^{-10} \mathrm{~mol} / \mathrm{l}$ were observed in the present study (Fig. 8). However, An significantly decreased cell proliferation and NA significantly

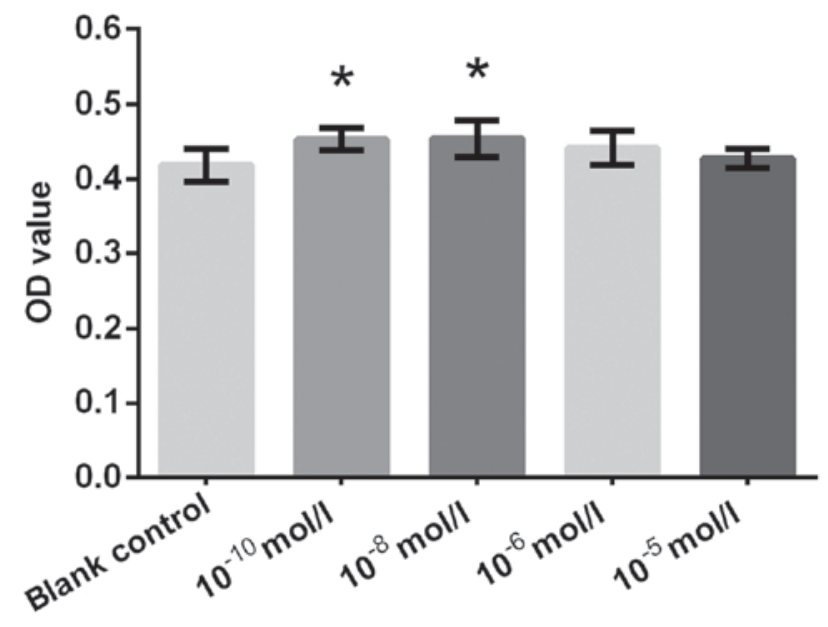

Concentration

Figure 7. Proliferative effect of testosterone. ${ }^{*} \mathrm{P}<0.05$ vs. blank control. OD, optical density.

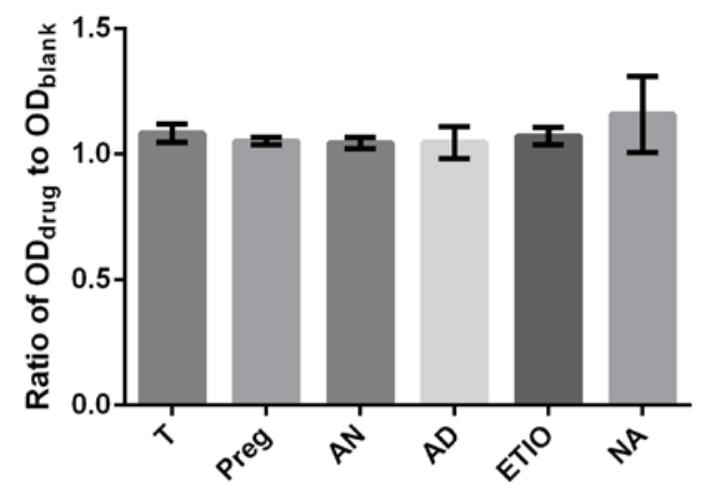

Figure 8. Comparison of the effects on proliferation rate between $\mathrm{T}$ and respective steroids (Preg, An, AD, Etio and NA) at concentrations of $10^{-10} \mathrm{~mol} / \mathrm{l}$. T, testosterone; Preg, pregnenolone; An, androsterone; AD, androstendione; Etio, etiocholanone; OD, optical density.

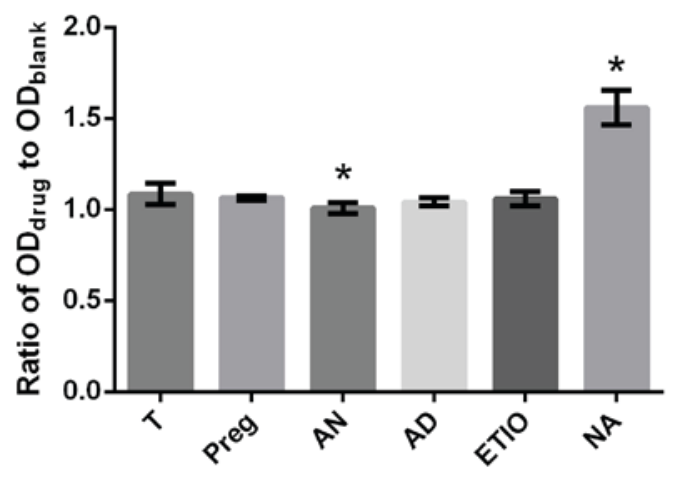

Figure 9. Comparison of the effects on proliferation rate between $\mathrm{T}$ and respective steroids (Preg, An, AD, Etio and NA) at concentrations of $10^{-8} \mathrm{~mol} / 1 .{ }^{*} \mathrm{P}<0.05$ vs. T. T, testosterone; Preg, pregnenolone; An, androsterone; $\mathrm{AD}$, androstendione; Etio, etiocholanone; $\mathrm{OD}$, optical density.

increased cell proliferation compared with $\mathrm{T}$ at a concentration of $10^{-8} \mathrm{~mol} / \mathrm{l}(\mathrm{P}<0.05$; Fig. 9). 


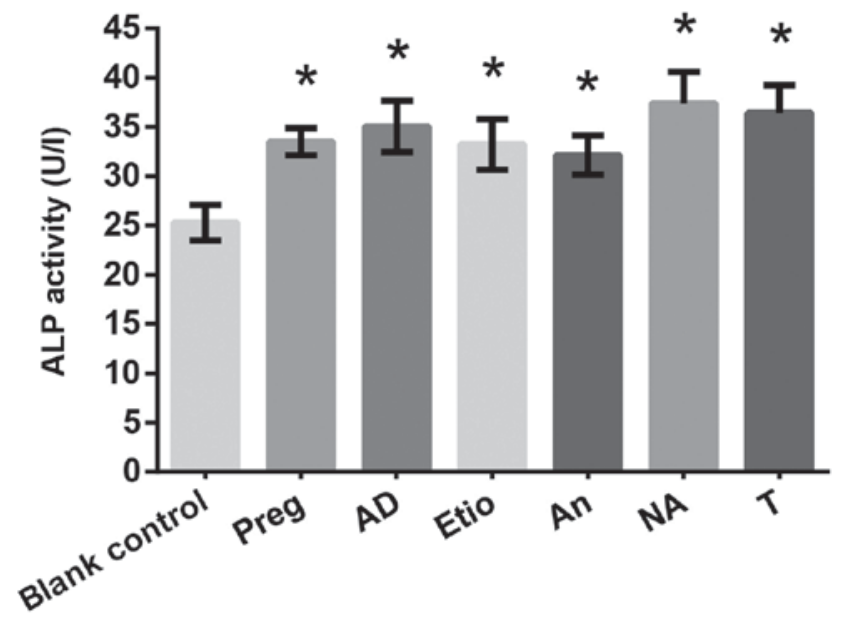

Figure 10. Effects of drugs (Preg, AD, Etio, An, NA and T) on alkaline phosphatase activity (U/l). "P<0.05 vs. blank control. T, testosterone; Preg, pregnenolone; An, androsterone; $\mathrm{AD}$, androstendione; Etio, etiocholanone; NA, nandrolone.

ALP activity. The results of the MTS assay indicated that Preg, AD, Etio, NA and T demonstrated enhancing effects on proliferation at concentrations of $10^{-10}$ and $10^{-8} \mathrm{~mol} / \mathrm{l}$, while An exhibited an effect at a concentration of $10^{-10} \mathrm{~mol} / \mathrm{l}$. Therefore, an ALP assay was performed with these steroids at a concentration of $10^{-10} \mathrm{~mol} / \mathrm{l}$. The results indicated that Preg, AD, Etio, An, NA and T significantly increased ALP activity compared with the blank control (Fig. 10).

Osteocalcin secretion. Osteoblasts were cultured with the drugs at a concentration of $10^{-10} \mathrm{~mol} / \mathrm{l}$, and a BGP assay was performed on day 5. As indicated in Fig. 11, Preg, AD, Etio, An, NA and T significantly increased BGP secretion significantly at a concentration of $10^{-10} \mathrm{~mol} / \mathrm{l}$, as compared with the blank control.

\section{Discussion}

A deficiency in sex steroids is well-established as a causative factor for osteoporosis and bone loss, and thus hormone replacement therapy is widely used in clinical practice (33-35). Although the role that androgens play in bone regeneration has been revealed to be via the estrogen receptors following conversion to estrogen $(36,37)$, certain studies have reported that androgens may affect bone regeneration independently $(17,20)$. Among the androgens, T and DHT were the main steroids explored in these studies (33). The present study demonstrated that Preg, AD, Etio, and An could improve the proliferation and differentiation of bone cells in vitro.

Although the effects of these steroids on bone health in vivo may not be an exact replication of those in vitro, their clinically active effects in treating osteoporosis are still worthy of consideration. Preg is a precursor of androgens and estrogens, and $\mathrm{AD}$ is a precursor of T, DHT and estrogens. An can be converted into DHT via $3 \alpha$-hydroxysteroid dehydrogenase and $17 \beta$-hydroxysteroid dehydrogenase, and could be considered to be a metabolic intermediate in its own right $(38,39)$. Therefore, androgens and progestin, and their metabolites, may promote bone regeneration.

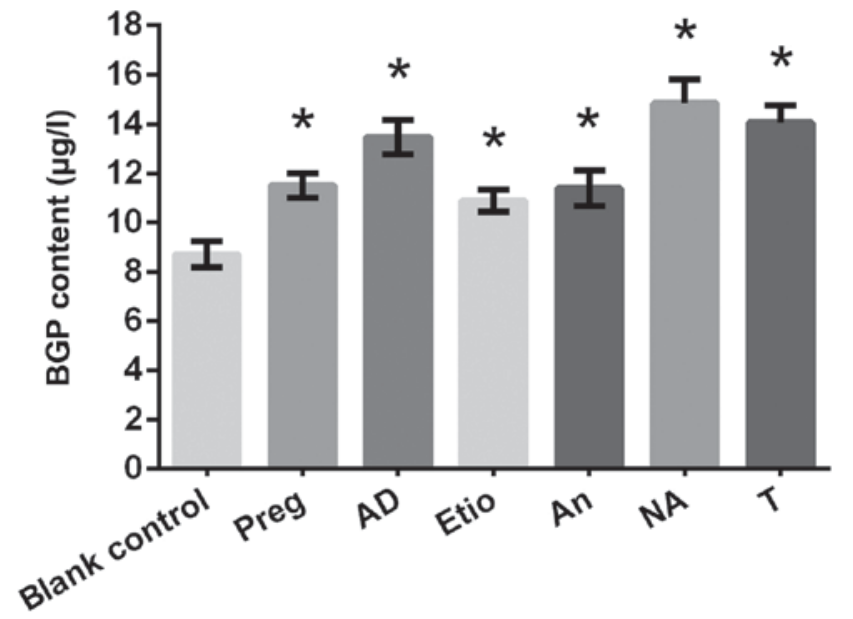

Figure 11. Effects of drugs (Preg, AD, Etio, An, NA and T) on the $\gamma$-carbox yglutamic-acid-containing protein content $(\mu \mathrm{g} / \mathrm{l})$. ${ }^{*} \mathrm{P}<0.05$ vs. blank control. T, testosterone; Preg, pregnenolone; An, androsterone; AD, androstendione; Etio, etiocholanone; NA, nandrolone.

The present study demonstrated that NA stimulated osteoblast proliferation more efficiently compared with $\mathrm{T}$ at concentrations of $10^{-8} \mathrm{~mol} / \mathrm{l}$. Nevertheless, the side effects of NA in clinical practice cannot be ignored. Nephrotoxicity of NA remains a multi-factorial and partly irreversible side effect (40). A previous study on Wistar female rats treated with NA decanoate revealed that administration of NA damaged uterine tissue and fertility (41). Etio and An have always been considered to be metabolites of androgens that possess no physiological effect $(42,43)$. However, to the best of our knowledge, this is the first study to demonstrate that Etio and An could improve osteoblast proliferation.

In addition to these active factors, the extracellular environment may greatly affect bone health. Bone health depends on a sufficient blood supply, since vascular networks provide nutrients, oxygen, and progenitor cells that are essential for bone function (44). Therefore, the effects of androgens and progestin on blood vessels need to be clarified in relation to bone maintenance. The proliferation of endothelial cell vessels is important for forming and/or renovating the extensive networks of blood vessels for bone regeneration and fracture healing. Furthermore, a previous study demonstrated that endothelial cells themselves enhanced bone formation (45). Certain evidence supports the beneficial effects of androgen on vascular functions. One study indicated that androgen stimulates endothelial cell proliferation via an androgen receptor/vascular endothelial growth factor/cyclin A-mediated mechanism (46). Additional investigations into the effect of Preg, AD, Etio, An and NA on these aspects should be conducted.

In conclusion, the present study demonstrated for the first time that Preg, AD, Etio, and An improved the proliferation of osteoblasts in vitro. These steroids also significantly increased ALP activity and BGP secretion of hFOB cells. These findings may potentially represent novel therapeutic strategies for the treatment of osteoporosis. Therapy with these individual agents, in combination (e.g. estrogen plus the weak androgen or estrogen plus Preg), or the application of progestogen and the weak androgen during the 'drug holiday' of bisphosphonate may be more effective and safe treatment strategies. 


\section{Acknowledgements}

Not applicable.

\section{Funding}

No funding was received.

\section{Availability of data and materials}

The datasets used and/or analyzed during the present study are available from the corresponding author on reasonable request.

\section{Authors' contributions}

$\mathrm{XCW}$ designed the study, performed the experiments, analyzed and interpreted the data and drafted and revised the manuscript. MQZ participated in the design of the study, and helped to analyze and interpret the data. All authors have read and approved the final version of the manuscript.

\section{Ethics approval and consent to participate}

Not applicable.

\section{Patient consent for publication}

Not applicable.

\section{Competing interests}

The authors declare that they have no competing interests.

\section{References}

1. Ellis SL, Grassinger J, Jones A, Borg J, Camenisch T, Haylock D, Bertoncello I and Nilsson SK: The relationship between bone, hemopoietic stem cells, and vasculature. Blood 118: 1516-1524,2011.

2. Felix R, Elford PR, Stoercklé C, Cecchini M, Wetterwald A, Trechsel U, Fleisch H and Stadler BM: Production of hemopoietic growth factors by bone tissue and bone cells in culture. J Bone Miner Res 3: 27-36, 1988.

3. Guntur AR and Rosen CJ: Bone as an endocrine organ. Endocr Pract 18: 758-762, 2012.

4. Cianferotti L and Brandi ML: Muscle-bone interactions: Basic and clinical aspects. Endocrine 45: 165-177, 2014.

5. Rendina E, Hembree KD, Davis MR, Marlow D, Clarke SL, Halloran BP, Lucas EA and Smith BJ: Dried plum's unique capacity to reverse bone loss and alter bone metabolism in postmenopausal osteoporosis model. PLoS One 8: e60569, 2013.

6. Faienza MF, Ventura A, Marzano F and Cavallo L: Postmenopausal osteoporosis: The role of immune system cells. Clin Dev Immunol 2013: 575936, 2013.

7. Armas LA and Recker RR: Pathophysiology of osteoporosis: New mechanistic insights. Endocrinol Metab Clin North Am 41: 475-486, 2012

8. Rachner TD, Khosla S and Hof bauer LC: Osteoporosis: Now and the future. Lancet 377: 1276-1287, 2011.

9. Charles JF and Aliprantis AO: Osteoclasts: More than 'bone eaters'. Trends Mol Med 20: 449-459, 2014

10. Clarke BL and Khosla S: Androgens and bone. Steroids 74 : 296-305, 2009

11. Gallagher JC and Tella SH: Prevention and treatment of postmenopausal osteoporosis. J Steroid Biochem Mol Biol 142: $155-170,2014$

12. Jackson RD and Mysiw WJ: Insights into the epidemiology of postmenopausal osteoporosis: The women's health initiative. Semin Reprod Med 32: 454-462, 2014.
13. Bowring CE and Francis RM: National Osteoporosis Society's position statement on hormone replacement therapy in the prevention and treatment of osteoporosis. Menopause Int 17: 63-65, 2011.

14. Tirabassi G, Biagioli A and Balercia G: Bone benefits of testosterone replacement therapy in male hypogonadism. Panminerva Med 56: 151-163, 2014.

15. Cartwright B, Robinson J, Seed PT, Fogelman I, and Rymer J: Hormone replacement therapy versus the combined oral contraceptive pill in premature ovarian failure: A randomized controlled trial of the effects on bone mineral density. J Clin Endocrinol Metab 101: 3497-3505, 2016.

16. Jo DG, Lee HS, Joo YM, and Seo JT: Effect of testosterone replacement therapy on bone mineral density in patients with Klinefelter syndrome. Yonsei Med J 54: 1331-1335, 2013.

17. Kasperk CH, Wergedal JE, Farley JR, Linkhart TA, Turner RT and Baylink DJ: Androgens directly stimulate proliferation of bone cells in vitro. Endocrinology 124: 1576-1578, 1989.

18. Drake MT and Khosla S: Male osteoporosis. Endocrinol Metab Clin North Am 41: 629-641, 2012.

19. Swartz CM and Young MA: Male hypogonadism and bone fracture. N Engl J Med 318: 996, 1988.

20. Nieminen MS, Rämö MP, Viitasalo M, Heikkilä P, Karjalainen J, Mäntysaari M and Heikkilä J: Serious cardiovascular side effects of large doses of anabolic steroids in weight lifters. Eur Heart J 17: 1576-1583, 1996.

21. Lamb DR: Anabolic steroids in athletics: How well do they work and how dangerous are they? Am J Sports Med 12: 31-38, 1984.

22. Bassil N, Alkaade S and Morley JE: The benefits and risks of testosterone replacement therapy: A review. Ther Clin Risk Manag 5: 427-448, 2009.

23. Frick KM, Kim J, Tuscher JJ and Fortress AM: Sex steroid hormones matter for learning and memory: Estrogenic regulation of hippocampal function in male and female rodents. Learn Mem 22: 472-493, 2015.

24. Devlin TM: Textbook of biochemistry: With clinical correlations (7th edition). Hoboken, New Jersey, 2010.

25. Kaminski RM, Marini H, Kim WJ and Rogawski MA: Anticonvulsant activity of androsterone and etiocholanolone. Epilepsia 46: 819-827, 2005.

26. Motofei IG: A dual physiological character for cerebral mechanisms of sexuality and cognition: Common somatic peripheral afferents. BJU Int 108: 1634-1639, 2011.

27. Gruyter WD: Concise encyclopedia biology. Berlin, 1996.

28. Marques DRC, Marques D, Ibanez JF, Freitas IB, Hespanha AC, Monteiro JF, Eggert M and Becker A: Effects of nandrolone decanoate on time to consolidation of bone defects resulting from osteotomy for tibial tuberosity advancement. Vet Comp Orthop Traumatol 30: 351-356, 2017.

29. Nawata H, Tanaka S, Tanaka S, Takayanagi R, Sakai Y, Yanase T, Ikuyama $\mathrm{S}$ and Haji M: Aromatase in bone cell: Association with osteoporosis in postmenopausal women. J Steroid Biochem Mol Biol 53: 165-174, 1995.

30. da Costa KJ, Passos JJ, Gomes AD, Sinisterra RD, Lanza CR and Cortés ME: Effect of testosterone incorporation on cell proliferation and differentiation for polymer-bioceramic composites. J Mater Sci Mater Med 23: 2751-2759, 2012.

31. Zoch ML, Clemens TL and Riddle RC: New insights into the biology of osteocalcin. Bone 82: 42-49, 2016.

32. Tuck SP and Francis RM: Testosterone, bone and osteoporosis. Front Horm Res 37: 123-132, 2009.

33. Weinstein RS, Jilka RL, Parfitt AM and Manolagas SC: The effects of androgen deficiency on murine bone remodeling and bone mineral density are mediated via cells of the osteoblastic lineage. Endocrinology 138: 4013-4021, 1997.

34. Diamond TH, Higano CS, Smith MR, Guise TA and Singer FR: Osteoporosis in men with prostate carcinoma receiving androgen-deprivation therapy: Recommendations for diagnosis and therapies. Cancer 100: 892-899, 2004.

35. Daniell HW, Dunn SR, Ferguson DW, Lomas G, Niazi Z and Stratte PT: Progressive osteoporosis during androgen deprivation therapy for prostate cancer. J Urol 163: 181-186, 2000.

36. Sessa G and Weissmann G: Differential effecs of etiocholanolone on phospholipid/cholesterol structures containing either testosterone or estradiol. Biochim Biophys Acta 150: 173-180, 1968.

37. Novak FJ and Lambert JG: Pregnenolone, testosterone, and estradiol in the migratory locust Locustamigratoria; a gas chromatographical-mass spectrometrical study. Gen Comp Endocrinol 76: 73-82, 1989. 
38. Penning TM, Burczynski ME, Jez JM, Hung CF, Lin HK, Ma H, Moore M, Palackal N and Ratnam K. Human 3alphahydroxysteroid dehydrogenase isoforms (AKR1C1-AKR1C4) of the aldo-keto reductase superfamily: functional plasticity and tissue distribution reveals roles in the inactivation and formation of male and female sex hormones. Biochem J 351: 67-77, 2000.

39. Kamrath C, Hochberg Z, Hartmann MF, Remer T and Wudy SA: Increased activation of the alternative 'backdoor' pathway in patients with 21-hydroxylase deficiency: Evidence from urinary steroid hormone analysis. J Clin Endocrinol Metab 97: E367-E375, 2012.

40. Tsitsimpikou C, Vasilaki F, Tsarouhas K, Fragkiadaki P, Tzardi M, Goutzourelas N, Nepka C, Kalogeraki A, Heretis I, Epitropaki Z, et al: Nephrotoxicity in rabbits after long-term nandrolone decanoate administration. Toxicol Lett 259: 21-27, 2016.

41. Belardin LB, Simão VA, Leite GA, Chuffa LG and Camargo IC: Dose-dependent effects and reversibility of the injuries caused by nandrolone decanoate in uterine tissue and fertility of rats. Birth Defects Res B Dev Reprod Toxicol 101: 168-177, 2014.
42. The biological properties of etiocholanolone. Combined clinical staff conference at the National Institutes of Health. Ann Intern Med 67: 1268-1295, 1967

43. Kaminski RM, Marini H, Kim WJ and Rogawski MA: Anticonvulsant activity of androsterone and etiocholanolone. Epilepsia 46: 819-827, 2005.

44. Roux BM, Akar B, Zhou W, Stojkova K, Barrera B, Brankov JG and Brey EM: Preformed vascular networks survive and enhance vascularization in critical sized cranial defects. Tissue Eng Part A, 2018. DOI: 10.1089/ten.TEA.2017.0493. (Epub ahead of print).

45. Pirraco RP, Iwata T, Yoshida T, Marques AP, Yamato M, Reis RL and Okano T: Endothelial cells enhance the in vivo bone-forming ability of osteogenic cell sheets. Lab Invest 94: 663-673, 2014

46. Cai J, Hong Y, Weng C, Tan C, Imperato-McGinley J and Zhu YS: Androgen stimulates endothelial cell proliferation via an androgen receptor/VEGF/cyclin A-mediated mechanism. Am J Physiol Heart Circ Physiol 300: H1210-H1221, 2011. 